\title{
CREATIVITY IN THE CONTEXT OF KAZAKH PROSE: WHY MASKS WONDER AROUND
}

\author{
Olga VALIKOVA* \\ Peoples' Friendship University of Russia, Faculty of the Russian Language and General Educational \\ Disciplines, Department of Russian Language and Intercultural Communication 6, \\ Miklukho-Maklaya str., 117198, Moscow, Russia
}

Received 18 November 2017; accepted 21 September 2018

\begin{abstract}
Particular genres are becoming more appealing in modern fiction, including dystopia, post-apocalyptic novels, and eco-horror. Post-industrial consciousness threatens the world due to environmental impacts and the loss of the most important living "landmarks" (orientations), i.e., dehumanization. In the "man versus nature" relations system, the Kazakh writer Aslan Zhaksylykov differentiates key elements in the "man versus man" paradigm: first, the "social animal" and secondly, the involuntary outcast or biological mutant. Starting with the Dreams of the Damned (first edition in 2006) literary cycle, in the creative thinking perspective the author discusses the "ilinxian" text phenomenon, the discursive space of connectomes and humanistic ideas embodied in ethno-cultural masks.
\end{abstract}

Keywords: connectome, ecocriticism, eco-text, Kazakh prose, "man versus nature" relations system, modern fiction, Zhaksylykov.

\section{Introduction: scientific outline of postmodern fictional texts}

Any fictional text in all its diversity is not just a product of culture, that is, a proper meaning, represented in a graphic form, but also a means of searching for this meaning, refracted through the "form-content" system. In this respect, postmodernity, with its special vision of the place of meaning (and the artist of the word) in society, literature, as well as specificity of the author-reader relations, is quite differentiated.

The basis of diversity of forms of creativity has the actual human activity, i.e. this or that material-practical or ideal transformation of reality. In the broad sense of the word, this kind of activity can be called human labour. Therefore,

"the essence of a human-being can be a kind of creative work, and the very phenomenon of creativity can act as the human ancestral essence. In this sense, the labour should be the affirmation of the human personality, and not at all by its alienation" (Batezhenko, 2011, p. 133).

${ }^{\star}$ Corresponding author. E-mail: olgavalikova23@gmail.com 
Thus, the postmodern text rather seems to be a kind of game with the reader, preceded by literary traditions, than (in fact) the atomized (separated) text of culture. In a way, this text is the center of all known meanings laid down in the previous products of culture - texts (Milorad Pavić, Boris Akunin, Victor Pelevin and others). Thus, as a matter of fact, being the aforementioned product of culture, it becomes the abode of intertextual, intermedial and other links, becoming a kind of intersection of meanings, which allows both arbitrary (Zhaksylykov, Pavić, Julia Kristeva) or clearly defined (Akunin) movement (in fact, cognitive action).

\section{Creative backstage of the cycle}

"Kazakh literature is rich in its philosophical and literary, spiritual and cultural content, characterized by a variety of artistic methods and innovative approach, which, not least, is associated with the search for a new aesthetic paradigm in the context of a global strengthening of intercultural and cross-country communication, further expanding the cultural dialogue of East and West, and - simultaneously - with the need to preserve and develop their national and cultural identity" (Askarova, 2016, p. 186).

The latter is whimsically connected with the interpretation of the majority of representatives of the medieval philosophy of human creativity as the creation of history. At the same time, the history itself is that form of being where finite human existences take part in the realization of God's design in the creation of the world. The scientific and artistic creativity in the Middle Ages appear as something of little significance and secondary. Literature, in this sense, by its nature is a construct with a creative beginning, and it is not stable, passive, but active and dynamic, i.e. one that is constantly evolving.

In this sense, Zhaksylykov is one of the most interesting writers of Kazakhstan. He "deviates" from the socialist realistic paradigm because of its tight limitations while creating his artistic world. Thus, the author is in search of realism and modernism; his protagonists make an attempt to develop an illogical and discrete world akin to chaos, trying to restore its primary harmony. The novel trilogy Dreams of the Damned (2005) by Zhaksylykov is a literary work that made the author, who is a doctor of philology, famous; it became a landmark event of the Kazakh prose. In 2004, the author was nominated for the Booker Prize for this very novel.

In terms of its composition, this novel is unusually complex and multidimensional, which makes it possible to put it on a par with such classic works of postmodernism as Thomas Pynchon's Gravity's Rainbow (1995, first edition in 1973). At the level of the original idea, it is comparable with Laurus by Evgenij G. Vodolazkin (2015, first edition in 2012).

The basis for writing this novel was laid after the author's visit to an orphanage located in Semipalatinsk region in Kazakhstan, in 1987. This orphanage became home for invalids, who suffered from nuclear radiation, which affected all the strata of the East Kazakhstan eco-complex. Meeting with disabled children was so shocking to the author that he promised to write a cycle of novels-fairy tales "about them and for them"; the novel Singing Stones by Zhaksylykov was created in the same year, however, it was published only ten years later; this work became the first part of the trilogy. 
One should note that the artistic text of this novel is characterized by a unique polycentric architectonics, comparable only with the image from the literary cycle The Chronicles of Amber by Roger Zelazny (1970-1991), in particular - with the pattern. So, each subsequent circle is an inductive "breed" of the previous one: this concentric organization is also comparable with the national musical genre of kuy (it is distinguished by a mixed metric, manifested in various forms, from playing to multi-frequency constructions organized according to the rondo principle). In its most complicated forms, kuy presents a multiple (at least 3 times), "circular" repetition of the main theme, alternating with episodes that differ from one another).

It is interesting that, despite its originality, the novel trilogy of this author can easily be inscribed in the context of fiction of that time (somewhat heterogeneous and unformed), which, according to Naum Lazarevich Leiderman, "is distinguished by a certain "dramatic effect engendered by the total spiritual crisis" (2005, pp. 47-48):

\begin{abstract}
"In this situation, one could see that the socialist realistic paradigm was weakly competitive. However, artistic systems leaning toward the modernist paradigm turned out to be in demand. Apparently, the growing awareness of social (and metaphysical) chaos found more appropriate forms of expression in them. The birth of Russian postmodernism occurred exactly in 1970s. Interpenetration of different artistic paradigms is intensified" (Osipova, 2008, p. 376).
\end{abstract}

So, the six mutant boys, the orphan girl and the old man (guardian) remain within the infected zone. On their eyes, few of the remaining people get sick and die from rare varieties of cancer: gradually the city turns into a ghost lost in the boundless steppes. A few years later the journalist arrives here in search of another sensational material and is trapped: there is no fuel left in his car; in an attempt to find people, he badly injures his leg, which forces him to stop overnight in one of the dilapidated buildings. There he finds a pile of notebookschronicles, written by children, and tries to restore the chain of previous events.

In this sense, the work is close to existentialism, in which attention is drawn to the subject of creativity. The subject of creativity of existentialists is a person who determines a certain irrational beginning of freedom, a kind of breakthrough of reasonable expediency and natural necessity, through which only the act of true creativity is possible:

"Existence as a way out of social and natural realizes something new in the world, which is usually called creativity. In general, both in the philosophy of life and in existentialism, the phenomenon of creativity, as a rule, is interpreted through the opposite of its technical and intellectual forms, the essence of creativity is recognized through its intuitive nature. It is carried out through ecstatic spiritual acts, through which the personality manifests itself as something indivisible, integral and unrepeatable" (Batezhenko, 2011, p. 137).

Despite the fact that Zhaksylykov refers himself to the followers of the classical tradition of Russian literature, he deliberately "breaks" from the canonical form of the novel image, creating a text of the most complex internal and external organization, a text-whirlpool, which we conditionally call ilinxian.

The term "ilinx" was first used by sociologist and culture researcher Roger Caillois to refer to games aimed at achieving ecstatic states through dizziness, rhythm, trance (in Greek, ilinx 
means "funnel"). We consider it acceptable to discuss an ilinxian text that stimulates vertigo in the reader. Trying to achieve a high empathic effect, the author rejects both the "multivector" novel epic, aesthetically developed by Leo Tolstoy, and from the "polyphonic" novel (Mikhail Bakhtin) by Fyodor Dostoyevsky. The latter leads to the fact that Zhaksylykov gives his heroes both the "right to vote", and the "freedom of thought". A network of numerous thought streams forming a discursive space of a complex type - a connectome, connects with the reader, the author and with each other protagonists.

The plot trajectories in all texts by Zhaksylykov are not simply blurred or "crossed"; they are located at different organization levels (temporal, spatial, real and unreal). Each change of each level is carried out through a "quantum leap" from one "whorl" of the plot spiral to the other. This text is a space of "discursive authorial intrusions" (Zhenett, 1998); these intrusions are realized through:

- prolepsis (an anticipatory story about a certain later event);

- analepsis (retrospective mentioning of an event preceding the point of the plot in which the reader is "located");

- syllepsis (anachronistic groupings, conditioned by a certain relationship - spatial, thematic, etc.);

- paralepsis (providing more information than permitted by the "focalization code", i.e., by the viewpoint);

- metalepsis (violation of the narrative norm, a deliberate transgression between the "world of the telling" and the "world of the told" (Zuseva-Ozkan, 2014, p. 19).

Genette also points to the philosophical effect of such "transitions", establishing a variable or unstable attitude between the narrator and the characters - a pronominal vertigo, "subject to a more free logic and a more complex understanding of personality" (1998, p. 33).

A "pronominal vertigo" is among the dominant artistic techniques of Zhaksylykov. In the course of the narrative, the entire paradigm of personal pronouns is involved ("I", "we", "you", "she", "he", "they", "it"), which "flow" one into another, changing the mode of what is happening.

The pronoun "you" is the compositional-narrative stimulus, which is used by the author to penetrate the consciousness of each protagonist, and, not least, to indicate his own position of being outside. The author (unlike the storyteller) never introduces himself, "pronominal markers" in his relation are presented only indirectly ("you", "they"), which brings him closer to the all-pervading cosmic mind, Demiurge. At the same time, "you-narration" is the principle of cooperation with the reader; however, this principle is "implicit": the reader is given the opportunity to identify himself/herself with the protagonist to whom the author is "addressed".

Thus, "you" is a pronoun-transposition, a zone of integration of three (simultaneously) streams of consciousness: the author, the protagonist and the reader. This is a kind of synapse (in neurophysiology - the "cohesion" point of neurons, through which one neuron transmits the information signal to another). The function of synapses in the text is performed not only by pronouns, but also by "cognitive portals" (such as the notebook-chronicle, which grants access of one protagonist to the consciousness of the other, through the other to the third one, etc.). Permanent change of the narrative foreshortening through the pronoun (and, consequently, through the activation of a new section of "consciousness", i.e., the new 
protagonist) allows Zhaksylykov to create a complex "discursive network", which we will denote as a connectome.

Let us specify that connectome in this case is not a direct borrowing of the term from neurophysiology; it is rather a metaphor that helps to describe complexity of the author's discourse. Zhaksylykov's text is not just a "stream of consciousness", it is a vast "network" of consciousnesses that mesh in synaptic "nodes". Thought streams of protagonists are "soldered", one flows into the other, having received a preliminary impulse, as a result of which the isolation, the individuality of consciousnesses is leveled. We see a set of consciousnesses, the transconsciousness that transcends the text, since both the author and the reader are connected to it. Thus, the author, the reader and all protagonists of the novel turn out to be connected by a united superconsciousness.

In neuroscience, a connectome is understood as the aggregate of all neural connections within an organism's nervous system. Each connectome is unique; unlike the genome, it is not determined by biological evolution, but is formed empirically and is subject to change (human DNA, on the contrary, remains unchanged). Each connectome accumulates memories, "produces" thoughts; it is responsible for the imagination. Violation of neural connections leads to cognitive disorders (decreased cerebral activity, hallucinations, etc.); Sebastian Seung describes scientific potential of the theory of connectivity in the book. Therefore, applying this term to the analysis of the novel space, we are aware of all the differences between its original and "metaphorical" meanings. Since any connectome in neurophysiology is individual, Seung believes that this very phenomenon determines identity of an individual; we, on the contrary, do not consider individual connectomes of protagonists (which, in principle, is impossible); we refer to the totality of all flows of consciousnesses (connections) within a certain transconsciousness (superconsciousness, metaconsciousness). Thus, the connectome serves us as a descriptive model of the most complex novel discourse (Seung, 2012, p. 26).

\section{Connectome in literary text}

The hypothesis of modern neuroscience is "I am my connectome", which in fact means "I am my brain". In our case, it is more correct to consider consciousness (logos). Let us add that Zhaksylykov is an adherent of the philosophical idea regarding the existence of the socalled world consciousness. Proceeding from this presupposition, communication within the unified consciousness can be rightly called a connectome. From this perspective, novels by Zhaksylykov present an example of "violation of the narrative pact". Note that in the collection of articles Metalepsis: Violations of the Narrative Pact such techniques are regarded as "rhetorical" (understood as a "transition" mechanism of the author and the reader from one level of narration to another) and "ontological" blurring the boundaries between the world of protagonists and the author's world (Leiderman \& Lipovecky, 2003).

Thus, the author, being "out of action", is present in each of his characters; one can observe "imposition" of consciousness, assimilation of several "cognitive fragments", which gives the 
author the opportunity to think, feel and live through his characters in the connectome space $^{1}$.

In the first sentence of the fragment, constructed as "you-narrative", the author addressed the "transpositive" figure of the cycle, to the journalist, who makes a report about ghost cities. A journalist (mask-name, which is conventional in this case) was lost in the steppe. He does not have fuel to get to the village, and his leg is dislocated. He is found by a local vagrant and settled in his barn where the journalist reveals a stack of notebooks-chronicles. Children living in an abandoned village filled these notebooks several years ago.

The notebook becomes a "cognitive portal" for the journalist, granting the reader's and the author's access to the next plot "pattern", refracted in a different consciousness. Koyan (hare) starts a new narration round, thinking about his mother. The "recording" is interrupted and resumed by the kid-duckling, for whom "mom" is an associative stimulus to his own "radiant" comparisons. For him, "mom" is Apke (which means "sister" in Kazakh), a Slav girl who cares about him. The kid's voice is "suddenly" replaced by the voice of the author, who first transfers the displayed image into the mode of the third person ("the kid looked at her", and then - into the "you-narrative", the subsequent integration of the author-readerprotagonist (duckling).

In such cases, metaprose researcher Robert Alter points out the effect of "ontological vertigo" that arises in the reader as a result of a constant change of "narrative levels" (Belous, 2013). The "temporal component" of Zhaksylykov's text is organized according to the same principle - "vertigo", "whirlpool" and "funnel". Thus, the novel involves four temporal layers and associated consciousness levels; Paola Dmitrievna Volkova proposed their classification in the book The Bridge over the Abyss (2014):

1. present time, characterized by industrial consciousness;

2. religious past, located in the timeless space of what has already occurred;

3. mythythological time, localized outside the space-time as such;

4. chthonic past, characterized by a "sticky film" of primitiveness.

The fifth level, the point of further "indivisibility" can be called chaotic timelessness, since there is no human life outside of time, there is only the Absolute Being, the counting of which begins from any point of space.

The whirlpool (ilinx) arises under the action of gravity and centrifugal force on the rotating (water) particles. The force of gravity is directed perpendicularly downwards; in our argument it is comparable with the diachronic axis (Ferdinand de Saussure). The centrifugal force increases when approaching the axis, while the resultant force $\mathrm{F}$ is directed

\footnotetext{
1 In Russian:

“Ty zazheg zapravlennuyu dnem lampu, ostorozhno otkryl tetrad's krasnoy oblozhkoy.

Krasnaya tetrad'

Instinktom Koyana ya dogadyvalsya, chto eto byla mama, no chto takoe mama ni ya, ni malysh, nikto iz nas tolkom sebe predstavit' ne mog. My znali, chto eto chto-to ochen' vazhnoe, znachitel'noe dlya nas, kakim-to obrazom svyazannoe s nashim poyavleniem iz Vselennoy Neizvestnosti.

Apke, kogda ty podnyalas' po lestnitse, gibel'noy, vetrovoy, pryamo k nebu, poslednemu, chernomu, khmuromu nebu, ya zaplakal, tikho pozval 'Mama'. Ya zaplakal tikhimi slovami, tenyami na nizkom potolke, struyami kosogo okna, za kotorym lokhmatilsya mrak i diko, slovno glaza koshek, sverkali zvezdy. I predvidya rasplatu, iz glubiny vremeni smotrel na nee malysh, smotrel na lunu v podnebes'ye i videl, predchuvstvoval, pronikal, providel vidimoe Materi s vysi. I ty plakal, zastonal golosom utenka, krasnogo, gologo, pisklyavogo" (Zhaksylykov, 2005, p. 194).
} 
obliquely. Thus, the funnel is horizontal on the "surface" and almost entirely vertical at the point of connection with the vertical axis. The horizontal axis can be designated as "synchronous".

In the aspect of the novel, the journalist lives in the "industrial present". There is no God in this time; all the people surrounding the journalist are hypocrites, inhabitants of urbanized "Sodom" and "Bedlam" ("I look sadly at our generation"). Hedonistic adaptation of society led to the formation of an empathetic vacuum, in which the ability of people to sympathize and to share is completely reduced. At this time interval, the journalist is a social being, thinking in accordance with conventional principles of his "role": an abandoned town is of interest for him as a "sensation", and not as a human tragedy. Once in the steppe, the journalist "passes" through the religious past (remembering God, his believing grandfather, prophets and their exploits, while the "connective" network allows the reader to penetrate the thoughts of various characters despite their remoteness in time).

Notebooks-chronicles connect the journalist with children and with the old man, and through their attitude one goes "deep" into the mythological past, the epoch of the Golden Age, when the winged Peri still flew across the sky, and Batyrs performed great feats in the name of valor and love.

Mythological past is pantheistic; nature in it is anthropomorphic, that is, like man. The capacity for metaphorical comprehension of the world makes this world closer and more knowable for the individual through a set of his/her own sensations and reactions. In this section of the narrative, the journalist begins to "see": the death of people in an ecocatastrophe now does not seem to him an "informational motive". The mask of the journalist is gradually replaced by the mask of the traveler.

Linear time is transformed for the journalist into a cosmological one. As a rule, events providing allowing new perceptions of historical experience give the possibility to see the history in its semiosis. This is a game of the present and the past - when the past is seen in the perspective of actual events of the present, defining the direction of this historical process:

"One can say that history deals with the otherworldly reality. The past (as it is interpreted as such), unlike the present, cannot be directly and sensually perceived [...]. Since the past is inaccessible to contemplation, the question of its existence is, in fact, a matter of belief. Cosmological consciousness presupposes correlation of events with some starting, initial state, which never disappears - in the sense that its emanation continues to be felt at all times" (Seung, 2012, p. 26).

The Golden Age becomes this starting state for Mugalim, children, and, subsequently, for the journalist as well ${ }^{2}$.

In chthonic time, the heroes immerse themselves in trance or in dreams, and this immersion becomes the key feature: in their ecstatic experiences they reach the limit of the times,

\footnotetext{
2 In Russian: “Tot vek nazvali Zolotym, glyadya na vek nyneshniy. Togda lyudi stepi ne znali zel'ya gor'kogo, d'yavol'skogo, ni tabaka durmannogo, ni travki pogibel'noy, po prichine kotorykh nyne sbivaetsya s puti velikoe mnozhestvo dush, ni oruzhiya, ubivayushchego t’my lyudskie plamenem i izlucheniem adskim. V te vremena lyudi chtili obychai drevnie, mladshie uvazhali starshikh, zheny pochitali muzhey, yunoshi ne smeli obizhat' devushek, detey zhe balovali i laskali, blagorodnye startsy, svedushchie v zakonakh bozh'ikh, vodili i pasli plemena. Spory reshalis' mudretsami ili sovetom stareyshin, tyurem i katorg ne bylo i v pomine. Nikto nikuda ne speshil, ne zagonyal v pot i strakh blizhnego svoego" (Zhaksylykov, 2005, p. 194).
} 
the sensation of non-being, and begin to create their universe anew, turning from abandoned disabled children into Demiurges of their own world. The latter brings together the main characters of the novel trilogy with popular characters described in a similar literary work by Ransom Riggs. However, masks-names in the $D D$ are an essential interpretative stimulus, which can be differentiated into two "classes":

1. Conventional or public masks, implying specific role determinism of the individual judging by his/her social position and performance of actions corresponding to the functional purpose of the mask (such are the masks of the journalist and the editor);

2. Archaic masks related to the mystery of the primordial (such masks are the names of children: kid-duckling, foal, hare, owl, wolf, boar, as well as the old man and sister).

The presence of a "masquerade" and masks themselves is another distinguishing feature of an ilinxian text, since the "immersion" of the reader into the "whirlpool" of the novel largely depends on the degree of his/her acceptance or non-acceptance of its characters as well as on the mechanism of the protagonist's "functional transfer", or projection on the reader. Masks as cultural concepts (archetypes) appeal to the unconscious and convey a whole range of additional ethno-cultural connotations.

\section{Whirling masks}

Both ideological and aesthetic identification of the novel cycle created by Zhaksylykov, its strict qualification "in terms of genre and direction" appears rather difficult. Zhaksylykov does not regard his cycle as postmodern, but in creating his artistic reality he uses the "toolbox" of postmodernism. In addition, this literary work includes trends of metaprose (intertextual references and allusions, experimental techniques, denial of the conventional plot, etc.), metanovel and novel with the author's intrusions. This refers to differentiation according to the "degree of author's presence" in the text. In terms of "comprehending" the reality, each novel in this cycle leans toward philosophical and wider metaphysical realism, although the form of their embodiment remains postmodern.

In the "foreshortening" of postmodernism, any artistic text appeals to a grand cultural phenomenon - the game. Like the game, a work of art is a priori conditional: both the author and the reader involved in co-creation, recognize conventionality of the depicted as one of the "rules" of interaction.

As Caillois notes, the nature of the game is incompatible with the well-known development of events. This statement is true both for the author who "does not know what his work turn into" (let us recall Alexander Pushkin, in Eugene Onegin (2008, first published in 1833) "unable to" unite Eugene Onegin and Tatyana, Tolstoy with his original idea of Anna Karenina ((2002, first edition in 1877), etc.) and for the reader. In order to obtain aesthetic pleasure, it is necessary to "read according to the rules", that is, consistently (if the work is classical) or following "the author's hint", if the text is experimental (Italo Calvino's If on a Winter's Night a Traveler (1982, first edition in 1979); Akunin's novel Quest (2008)). The transition from the outset to the epilogue is a kind of "violation of the agreement" with the author; while meaning in this "game" (i.e., reading) disappears. 
Caillois distinguishes four main classes of games: agonistic (competitive), mimetic (imitative, simulative), aleatic (unpredictable, hazardous) and ilinxian (based on vertigo, ecstatic games) (2007).

The artwork integrates the above characteristics, in particular:

a) simulation of reality, "imitation", or mimesis, from the ontological viewpoint and "mimicry" in the aspect of artistic style (from actual "imitation" as a genre to stylization, "echoing", transformations of precedent texts, imitation, etc.);

b) competition (in producing texts with potential canonicity or "truth"; compare Vasily Zhukovsky versus Pushkin, acmeists versus symbolists, etc.);

c) "unpredictability", alea (initially for the author, later for the reader).

To some extent, the effect of readers' expectations is realized through the genre (for example, the denouement of the tragedy is righteously expected as "unhappy", the novel form determines relevant dynamics of the narrative, etc.), but the outcome of the novel in terms of "specifics of events" remains unknown until the very end.

"Ilinxality", or the potential for "vertigo", is not inherent in every text. We have already noted that this property of the game - and the text - depends on how "space is organized" both cultural and literary. Let us try to determine what "ilinxality" in culture means.

The term "ilinx" ("funnel", "whirlpool") was proposed by Caillois (2007) with a view to describe ecstatic collective states in archaic cultures of Asia, Africa, Australia and America. Societies in which "the mask and obsession prevail" were called "chaotic" by the researcher. Masks and trance are inextricably linked. Masks perform the sacred function of a mediator between different worlds, when the orderliness of the world order is intentionally "abolished" for the acquisition of a new life by society. The mask turns the participants into gods, spirits, ancestral beasts (in the literary cycle of Zhaksylykov, "masks" are presented by the following names: Zhan (soul), Borya (wolf), Uku (owl), Koyan (hare), duckling, Taibala (foal), etc.).

The main characters of the cycle are social "denied persons", mutant children abandoned by their own parents and forgotten by society. They survive in the territory of a depressed military town. Each of these children is "endowed" with a certain physical deformity: the kid-duckling has a somatic disproportion, he has wide flattened feet with webbed fingers, which makes it impossible to move independently. The hare has muscular dystrophy and a disfigured face, like the wolf (whose disease is known as Daphne mezereum); the same refers to the boar with monstrous fangs and the owl with its graves' disease. The most agile and frisky of all these children is the foal, who is a well-built boy with a slight strabismus ${ }^{3}$.

In the social aspect, these are people without fate. It is therefore not by chance that Zhaksylykov characterizes them as "damned" (an allusion to the novel by Victor Hugo) and "humiliated and insulted" (reference to the work of Dostoyevsky). For people of the outside world, they are "mutants", "freaks", referred to as an extra link in the process of biological evolution. In the archaic societies of Asia, Africa and Australia, children with such deviations were sacrificed; "weak" children, that is, children that were unable to survive in military

\footnotetext{
${ }^{3}$ In Russian: "V nekoem ponimanii upomyanutyy tekst mozhno interpretirovat' v kachestve avangardnogo akta, sostoyashchego v sootnesenii odnoy s drugoy refleksiey - refleksiey avtora (khudozhnika) i refleksiey sozertsatelya (zritelya). Pri etom nado uchest', chto v ilinksal'nyy tekste chitatelyu zdes' prikhoditsya brat' na sebya funktsii tvortsa ili, po men'shey mere, sotvortsa" (Feshchenko, 2008, p. 150).
} 
conditions, were killed both in the Viking tribes and in all well-organized city-states of the ancient world, such as Sparta. Zhaksylykov emphasizes lack of intensive humanization of the society since its "chthonic past": social murder has replaced social assassination.

In this novel, the "structure" of an ideal society without discrimination based on "somatic characteristic" is the girl Apke (sister). She is the only healthy child, "different" with respect to the remaining "Big Hero 6" (mutant children). The sister does not reject them, accepts every boy as her brother; at night, she is on duty at the kid-duck's bed. She helps them to believe that they are worthy of life, that man is created - for life.

The carnival of events occurring through the introduction of names - totems into the text, that is, masks, transforms the narrative into a metaphysical dimension. Thus, according to researches carried out by Zhanar Karakozova (Hasanov \& Karakozova, 2011), the steppe wolf is the totem-ancestor of the entire Kazakh ethnos, patron and defender of the community. The horse is the messenger of the upper world, the allegory of the indomitable spirit, the symbol of an indestructible connection with the cosmos. The owl is a bird dedicated to the moon, a guide to the mighty element of the unconscious. The boar presents personification of vitality, the furious and fearless power of the Earth. In the text of Zhaksylykov, the archetype "BOAR", which also carries the "destruction" semantics (e.g., "Caledonian boar") is specified through the meaning of "ability to survive". The only person who cares for the children of the zone is the old master. The mask "old man" is associated with the memory of the past, the voice of ancestors, and the history of the kind.

The arrival of masks should rejuvenate and resurrect society. The violent "spinning" of the masks leads to obsession, causes nonsense along with a massive "dream". Simulation becomes a collective vertigo. As Caillois sums up, "masks are social bonds" (2007). In order to achieve the effect of a "total frustration of the senses", the performer (a direct participant of the ecstatic experience) resorts to various "tricks": severe austerities, alcoholic beverages that empower consciousness, rhythmical dances and music, hypnosis, etc. Thus, one of the protagonists in this cycle, Zhan ("spirit", "soul" in Kazakh) lives under monotonous hard labor, constant hunger and hops. Mutant children, led by the old man, live on the "leper" land and constantly experience the impact of radiation, which leads to irreversible mental changes, that is, "a conscious dream" ("life as a dream") - the permanent state of each protagonist.

"Disorder of feelings" is an indispensable condition for immersion in chaos; Caillois (2007) believes that mind in a different state is unable to endure entropy (metalepses). (It is not surprising that protagonists-madmen and/or chronic, incorrigible alcohol and drug addicts appear in the texts of Russian postmodern works. These are the "actors" described in such works as Moscow-Petushki (2007, first edition between 1969 and 1970) and Walpurgis Night, Or the Steps of the Commander (2014, first edition in 1985) by Venedikt Erofeev, in $A$ School for Fools (2015, first edition in 1976) and Between Dog and Wolf (2017, first edition in 1990) by Sasha Sokolov, in The Life of Insects (1999, first edition in 1993) by Pelevin, etc.).

It should be noted that Zhaksylykov's texts are closely related to the shamanic culture of Central Asia.

They include buksy (shamans), masks-totems, masks-spirits; all the characters are experiencing collective trance in the space of the connectome - the unified consciousness. As Mircea Eliade (1994) notes, during the "immersion" shamans (buksy) not only travels 
between different worlds, but creates anew the universe of the soul, restoring its integrity and harmony. Trance in chaotic societies was called the invasion of God. This act can be designated as "shamanistic ritual", i.e. "creation of the world from chaos". It is followed by a symbolic "loss of memory", marking the final break with the past and a new beginning of life.

The possessed turn out to be mummers, i.e. they wear the mask of the spirit or deity that infuses them and imitate his/her characteristic actions. The complex of actions performed by "mummers" should be expressive, in other words, it should fully correspond to the mask and related scenarios. The mask contributes to the "rampage of instinctive, irresistible forces" that returns the performer to a chaotic "over-temporal" space and recreates his world anew. Thus, protagonists of Zhaksylykov's cycle correspond to their totemic incarnations: Uku (owl) is phlegmatic and sleepy during the day, transforms at night, becoming a dexterous and keen rat hunter; Taibala (the foal) is an unsurpassed runner, for whom running is another way to achieve "vertigo"; Kabanbai is a real boar with growing fangs. The hare is coward like a real hare, but fear in it is transformed into a higher sensibility, the ability to foresee any danger.

The kid-duckling is a special figure in this cycle. In terms of collective archetype, this is the embodiment of "otherness"; it also has the potential for reuniting with "its own circle". The ethnocultural "layer" of masks correlates with the ethnic myth about the creation of the world. When there was nothing but the world ocean, two deities, Tengri and Erlik, floated on its surface in the guise of ducks. Erlik dived to the very bottom of the ocean and brought a clod of clay to the surface, from which the Earth was created. The duck in the Kazakh ethnoculture, thus, is symbolically linked with the creation of the world.

The kid has a phenomenal memory and an unusual imagination, that is, he is the bearer of a higher power - Creativity. The kid remembers the day, the hour and the moment when he was born; he remembers his sensations in the mother's womb, but he does not remember the mother herself: dad separated them immediately after birth, sending the duckling to the orphanage for "special" children. Throughout his later life, the kid regrets and mourns the mother cuckoo, feels her pain, remorse and impotence. In the state of "sleep" he sees her loneliness, takes over her depression, and there is nothing but love-pity and forgiveness in his soul.

The latter is organically connected with the genealogy of the philosophy of creativity itself, which can be traced back to Plato. Every transition from non-being to being is creativity. In fact, the same idea is laid in the foundation of the central dogma of Christianity about the creation of the world from nothing ("creatio ex nihilo"). In philosophical and methodological terms, this precept formed a whole theory - creationism, organically fitting into postmodern discourse. Until the Renaissance, creativity was interpreted either as an impersonal, extra-individual process, or as a process of the Divine. It is curious that the idea of personal creativity was born from the bosom of theoretical theology. God creates the world, and man participates in the realization of the divine plan for the world. Personal action, an individual decision as a form of complicity in the creation of the world by God create the prerequisites for understanding creativity as a unique personal act (Feshchenko, 2008, p. 145).

Therefore, the reality is "stratified", the existence of protagonists affects its physical and metaphysical levels. In the "real" world, the life of abandoned and weak orphans passes; 
however, there are powerful souls in the transcendental world behind them, the Demiurges of the new universes living according to the new laws: the Law of Love, the Law of Truth and the Law of Unity.

The storyline in the texts under consideration is not equivalent to the plot: the action of novels develops in several space-time dimensions, which are organized according to the principle of polycentric composition. "Layers of the plot" are like a funnel, when the reader's transition to a new level occurs under the action of another synaptic impulse or authorial intrusion - this is an external ilinxation of the text, affecting architectonics. The "meaningful" ilinxation is achieved through "pronominal vertigo" in the connectome and synapses; it connects "streams of thought" of protagonists with each other, as well as through carnival and masks, whose purpose is to contribute to the acquisition of spiritual integrity of each protagonist.

Special "ilinxation zones" in all novels are in italics. These streams of consciousness are uncontrollable in the trance process, they are rhythmically proportioned and meaningfully "concentrated": in these very sections of the text written in free verse the Tengri deity, the Demiurge of nomad cosmogony, the image of the idyllic meadow, on which the marvelous Mayan cow grazes (world abundance) and over which the Bodone quail flies; the image of the World Mountain, symbolizing harmony and order. This experience is transpersonal; it is experienced by all participants in the "novel vertigo". It signifies a special process - shamanistic ritual, when the soul of the dreamer is reborn and purified (it is not accidental that tears become the leitmotif of these text fragments).

\section{Conclusions}

For a true understanding of the phenomenon of creativity and finding out what it really is in essence, it is necessary to turn to the methodological foundations of creativity, to find the methodological approach most appropriate to the essence of the problem, based on which it is possible to solve the very problem, find and define the essence the phenomenon of creativity.

Thus, we are dealing with the ilinxian text, built on the principle of connective "funnel", which gives the author the opportunity to create a textual model of the Divine Reason, which, in turn, develops the idea of world monism. According to Zhaksylykov, humanity, torn apart by wars, hatred and vanity, is nevertheless "spiritually interconnected". The ilinxian (funnelshaped) text organization helps the author to achieve a high level of cooperation with the reader. As Zhaksylykov believes, "books are written because of ineffable burden"; therefore, he creates a text model capable of causing an empathic effect on the addressee, to convey the idea that everything is interconnected and there is nothing in the world "apart from" these interconnections. Connections remain, even being broken. Disorder in connections present in a human genome does not make man non-human.

$D D$ presents the author's attempt to convey the idea of higher humanism, and obligation of a Man before a Man to society. To date, the novel cycle of Zhaksylykov is the only sample of the ilinxian text in the Russian-language literature. 


\section{References}

Akunin, B. (2008). Kvest. Moskva: Astrel.

Askarova, A. Sh. (2016). Osnovnye tendencii russkojazychnoj hudozhestvennoj literatury Kazahstana v postsovetskij period. Stephanos, 3(17), 185-191.

Batezhenko, V. V. (2011). Fenomen tvorchestva: opyt filosofsko-ideologicheskogo analiza. Vestnik OGU, 11, 132-138.

Belous, A. (2013). Polifonicheskij roman F. M. Dostoevskogo v zerkale hristianskogo osoznanija. Vestnik Tomskogo Gosudarstvennogo Universiteta, 371, 7-10.

Caillois, R. (2007). Igry i lyudi. Stat'i i esse po sotsiologii kul'tury. Moskva: OSU.

Calvino, I. (1982). If on a winter's night a traveler. Toronto: L\&OD Key Porter.

Dmitrievna Volkova, P. (2014). Most cherez bezdnu. Kn. 1. Moskva: Zebra.

Eliade, M. (1994). Svjashhennoe i mirskoe. Moskva: MGU.

Erofeev, V. (2007). Moskva-Petushki. Moskva: Vagrius.

Erofeev, V. (2014). Walpurgis night: a tragicomedy in five acts. Series: Margellos World Republic of Letters Book. New Heaven \& London: Yale University Press.

Feshchenko, V. V. (2008). Semiotika tvorchestva i lingvistika kreativnosti. Obshhestvennye nauki i sovremennost', 6, 143-150.

Genette, G. (1998). Die Erzählung (p. 3). UTB, Stuttgart, Auflage.

Hasanov, M. Sh., \& Karakozova, Zh. K. (2011). Kosmos kazahskoj literatury. Almaty: Jevero.

Lazarevich Leiderman, N. (2005). Traektorii “jeksperimental'noj jepohi”: Vvedenie. Russkaja literatura XX veka: zakonomernost’ istoricheskogo razvitija. Kn. 1: Novye hudozhestvennye strategii. Ekaterinburg: UrO RAS.

Leiderman, N., \& Lipovetsky, M. (2003). Sovremennaja russkaja literatura, 1950-1990s. Vol. 2. Moskva: "Academy".

Osipova, O. V. (2008). Obraz pojeta v dialoge M. Cvetaevoj i A. Bloka. Izvestija Rossijskogo gosudarstvennogo pedagogicheskogo universiteta im. A. I. Gercena, 74(1), 375-378.

Pelevin, V. (1999). The life of insects. London: Faber \& Faber.

Pushkin, A. (2008). Eugene Onegin. Series: Penguin Classics. New York: Penguin Books.

Pynchon, Th. (1995). Gravity's rainbow. New York: Penguin Books.

Seung, S. (2012). Connectome: how the brain's wiring makes us who we are. New York: Penguin.

Sokolov, S. (2015). A school for fools. New York: New York Review Books.

Sokolov, S. (2017). Between dog and woolf. New York: Columbia University Press.

Tolstoy, L. (2002). Anna Karenina. New York: Penguin Books.

Vodolazkin, E. (2015). Laurus. New York: Oneworld Publications.

Zhaksylykov, A. (2005). Sny okayannykh: trilogiya. Almaty: Almatinskiy izdatel'skiy dom.

Zelazny, R. (1970-1991). The chronicles of amber. New York: Nelson Doubleday / Science Fiction Book Club. Zhenett, Zh. (1998). Figury. T. 1-2. Moskva: Izdatelstvo im. Sabashnikovyh.

Zuseva-Ozkan, V. B. (2014). Istoricheskaja pojetika metaromana: Monografia. Moskva: Intrada.

\section{Acknowledgements}

The author is extremely grateful to Doctor of Sciences (Linguistics), Prof. Uldanai Maksutovna Bakhtikireeva, who is the pioneer in the field of research of bilingual art texts in Russia and thanks to which this work was carried out. 


\title{
KŪRYBIŠKUMAS KAZACHŲ PROZOS KONTEKSTE: KODĖL KAUKĖS KELIA SUSIDOMĖJIMĄ
}

\author{
Olga VALIKOVA
}

\section{Santrauka}

Tam tikri žanrai šiuolaikinèje grožinèje literatūroje, įskaitant distopiją, poapokaliptinius romanus ir ekologijos siaubą, iggyja daugiau patrauklumo. Postindustrinè sąmonè kelia grèsmę pasauliui dèl poveikio aplinkai ir dèl pačių svarbiausių gyvenimo gairių (orientyrų) praradimo, i.e. dehumanizacijos. „Žmogus versus gamta“ santykių sistemoje kazachų rašytojas Aslanas Zhaksylykovas atskiria pagrindinius „žmogus versus gamta“ paradigmos elementus: pirma, „socialinị gyvūną“ ir, antra, nevalingai atstumtąji ar biologinị mutantą. Pradėdama nuo Pasmerktujų svajonių (pirmasis leidimas pasirodè $2006 \mathrm{~m}$.) literatūros ciklo, kūrybinio mąstymo perspektyvoje autorè aptaria ilinx teksto fenomeną, diskursyviąją konektomų ir humanistinių idejų, reiškiamų etnokultūrinèmis kaukèmis, erdvę.

Reikšminiai žodžiai: konektomai, ekologijos kritika, ekologijos tekstas, kazachų proza, „Žmogus versus gamta“ santykių sistema, šiuolaikinė grožinė literatūra, Zhaksylykovas. 